\title{
Kemampuan Berpikir Rasional Siswa Berdominasi Otak Kiri dalam Menyelesaikan Soal PISA
}

\author{
Dian Fitra ${ }^{1, *}$, Meta Silvia Gunawan ${ }^{2}$ \\ ${ }^{1,2}$ Universitas Adiwangsa Jambi \\ *fitra03dian@gmail.com
}

\begin{tabular}{|l|l|l|l|}
\hline Received : 28-09-2020 & Revised: $15-05-2021$ & Accepted: 20-05-2021 & Published: 06-06-2021 \\
\hline
\end{tabular}

\begin{abstract}
ABSTRAK
Penelitian ini bertujuan untuk mengetahui kemampuan berpikir rasional siswa berdominasi otak kiri dalam menyelesaikan soal PISA. Penelitian yang dilakukan merupakan penelitian kualitatif deskriptif. Subjek penelitian ini adalah siswa berusia 15 tahun yang berdominasi otak kiri sebanyak dua orang. Subjek berdominasi otak kiri diperoleh dengan melakukan tes inventori menggunakan instrumen yang dikembangkan oleh John Parks Le Tellier. Teknik pengumpulan data dalam penelitian ini menggunakan teknik tes dan wawancara. Instrumen tes yang digunakan dalam penelitian ini adalah soal PISA konteks "Dukungan untuk Presiden". Kredibilitas data dilakukan dengan melakukan triangulasi metode yaitu membandingkan hasil tes dan wawancara. Teknik analisis data dilakukan dengan tahapan 1) mereduksi data dari kumpulan data yang diperoleh, 2) selanjutnya data tersebut disajikan untuk ditelaah, 3) melakukan verifikasi atau penarikan kesimpulan. Penelitian ini menyimpulkan bahwa kemampuan berpikir rasional yang baik dimulai dengan pemahaman informasi yang baik. Pemahaman informasi yang baik akan menuntun seseorang pada tahapan berpikir rasonal selanjutnya dengan baik pula seperti yang dilakukan siswa OK1. Sebaliknya, kesalahan seseorang dalam memahami informasi mengakibatkan kesalahan pada tahapan berpikir rasional selanjutnya. Pada akhirnya kesalahan tersebut mengarahkan kepada penarikan kesimpulan yang salah seperti yang dilakukan oleh siswa OK2.
\end{abstract}

Kata Kunci: Kemampuan Berpikir Rasional, PISA, Berdominasi Otak Kiri

\begin{abstract}
This study aims to determine the rational thinking ability of students who are dominated by the left brain in solving the PISA task. This research was descriptive qualitative research. The research subjects in this study were two students aged 15 years who were dominated by the left brain. Leftbrain dominant subjects were obtained by conducting an inventory test using an instrument developed by John Parks Le Tellier Data collection techniques used in this study were test and interview techniques. The test instrument used in this study was the PISA task in the context of "Support for the President". The data credibility was done by triangulating the method, namely comparing the test results and interviews. The data analysis technique was carried out in some stages 1) reducing the data from the collected data set, 2) then the data is presented for review, 3) verifying or drawing conclusions. Based on research result, it is concluded that good rational thinking ability begin with a good understanding of information. Good comprehension of information will lead someone to the next stage of rational thinking as well as what OK1 does. Conversely, someone's mistake in understanding information results in errors at the next stage of rational thinking ability. In the end, this error leads to drawing the wrong conclusions as done by OK2.
\end{abstract}

Keywords: Rational Thinking Ability, PISA, Left-brain dominant 


\section{PENDAHULUAN}

Program for International Student Assessment (PISA) adalah salah satu studi yang dilakukan untuk melihat kemampuan literasi matematika siswa. Salah satu keunikan soal PISA adalah penggunaan konteks. Konteks adalah situasi yang ada dalam soal yang diberikan. Hal ini sejalan dengan kurikulum Indonesia yang menginginkan siswa mampu mengaitkan pengetahuannya dengan konteks masyarakat dan lingkungan sekitar (Kemendikbud, 2016). Selanjutnya sebagai upaya meningkatkan kualitas pembelajaran di Indonesia, beberapa peneliti juga mengembangkan pembelajaran yang menggunakan konteks. Salah satu penelitian yang telah dilakukan adalan pembelajaran penjumlahan pecahan menggunakan konteks olahraga renang (Putri, Gunawan, \& Zulkardi, 2017), meningkatkan kualitas pembelajaran menggunakan pendekatan problem-solving (Artika \& Karso, 2019; Maulani, Ruseffendi, \& Kustiana, 2019), menggunakan model problem based learning (Septian \& Komala, 2019; Soleh, Setiawan, \& Haqi, 2020), dan menggunakan pendekatan realistic mathematic education (Wulandari, 2019). Penerapan dari hasil penelitian ini diharapkan mampu menghilangkan stigma siswa terhadap matematika yang merupakan kumpulan angka dan simbol (Kemendikbud, 2014).

Hasil studi Program for International Student Assessment (PISA) Indonesia pada tahun 2018 menunjukkan bahwa kemampuan literasi matematika siswa indonesia masih berada di bawah rata-rata negara maju dan berkembang lainnya (OECD, 2019). Banyak penelitian yang telah dilakukan agar kemampuan literasi matematika dapat meningkat dan lebih baik kedepannya. Beberapa penelitian yang sejalan dengan tujuan tersebut adalah pengembangan soal serupa PISA menggunakan konteks cabang olahraga Angkat besi (Fitra, Putri, \& Susanti, 2018a), konteks cabang olahraga Lari (Fitra, Putri, \& Susanti, 2018b). Hal ini bertujuan untuk membiasakan siswa mengerjakan soal-soal yang serupa dengan soal PISA. Selain itu, juga terdapat beberapa penelitian yang bertujuan untuk mengetahui kesulitan siswa dalam menyelesaikan soal PISA seperti penelitian tentang kesulitan mengubah bentuk permasalahan sehari-hari ke bentuk formal matematika (Jupri \& Drijvers, 2016). Selain itu, kesalahan yang dilakukan siswa adalah ketika mereka telah memperoleh solusi matematika dari permasalahan yang diberikan tidak diikuti dengan interpretasi dari solusi tersebut terhadap konteks/situasi yang diberikan (Lutfianto, Zulkardi, \& Hartono, 2013; Septian, Darhim, \& Prabawanto, 2020).

Dari penjelasan di atas mengenai kesalahan yang dilakukan oleh siswa Indonesia, peneliti merasa tertatik untuk menelusuri bagaimana kemampuan berpikir rasional siswa dalam menyelesaikan soal PISA (Jusniani, 2018). Kemampuan berpikir rasional ini 
merupakan salah satu kemampuan berpikir yang penting dalam membantu untuk mencapai tujuan (Baron, 2008). Kemampuan berpikir rasional dalam penelitian ini merujuk pada sepuluh indikator menurut Lawson (Lawson, 1980), yaitu: Mengingat; Membayangkan; Mengelompokkan; Generalisasi; Membandingkan; Mengevaluasi; Menganalisa; Sintesis; Deduksi; Kesimpulan. Sepuluh Indikator berpikir rasional menurut Lawson ini diharapkan mampu untuk dapat menelusuri pada tahapan mana siswa melakukan kesalahan, sehingga hasil penelitian ini nantinya dapat digunakan sebagai data awal yang akan digunakan untuk meningkatkan kemampuan berpikir rasional siswa dengan memberikan perlakuan khusus yang sesuai dengan kesalahan yang dilakukan.

\section{METODE PENELITIAN}

Jenis penelitian ini adalah kualitatif deskriptif. Penelitian yang menekankan pada analisis dari proses berpikir secara induktif yang bergerak secara dinamis terhadap fenomena yang diamati dan senantiasa tetap menggunakan logika ilmiah (Gunawan, 2013).

Subjek penelitian ini adalah siswa kelas X Sekolah Menengah Kejuruan swasta yang ada di kota Jambi. Subjek penelitian yang dilibatkan adalah subjek yang berusia 15 tahun sesuai dengan subjek PISA yang berjumlah 32 orang. Selanjutnya peneliti melakukan tes inventori terhadap siswa tersebut untuk memperoleh siswa yang berdominasi otak kiri. Instrumen tes inventori yang digunakan ini dikembangkan oleh John Parks Le Tellier (DePorter \& Hernacki, 2013). Instrumen tes inventori tersebut terdiri dari 15 kelompok kata, dan disetiap nomor terdiri dari empat kelompok kata. Bentuk instrumen tes inventori dapat dilihat pada gambar 1 di bawah ini. 


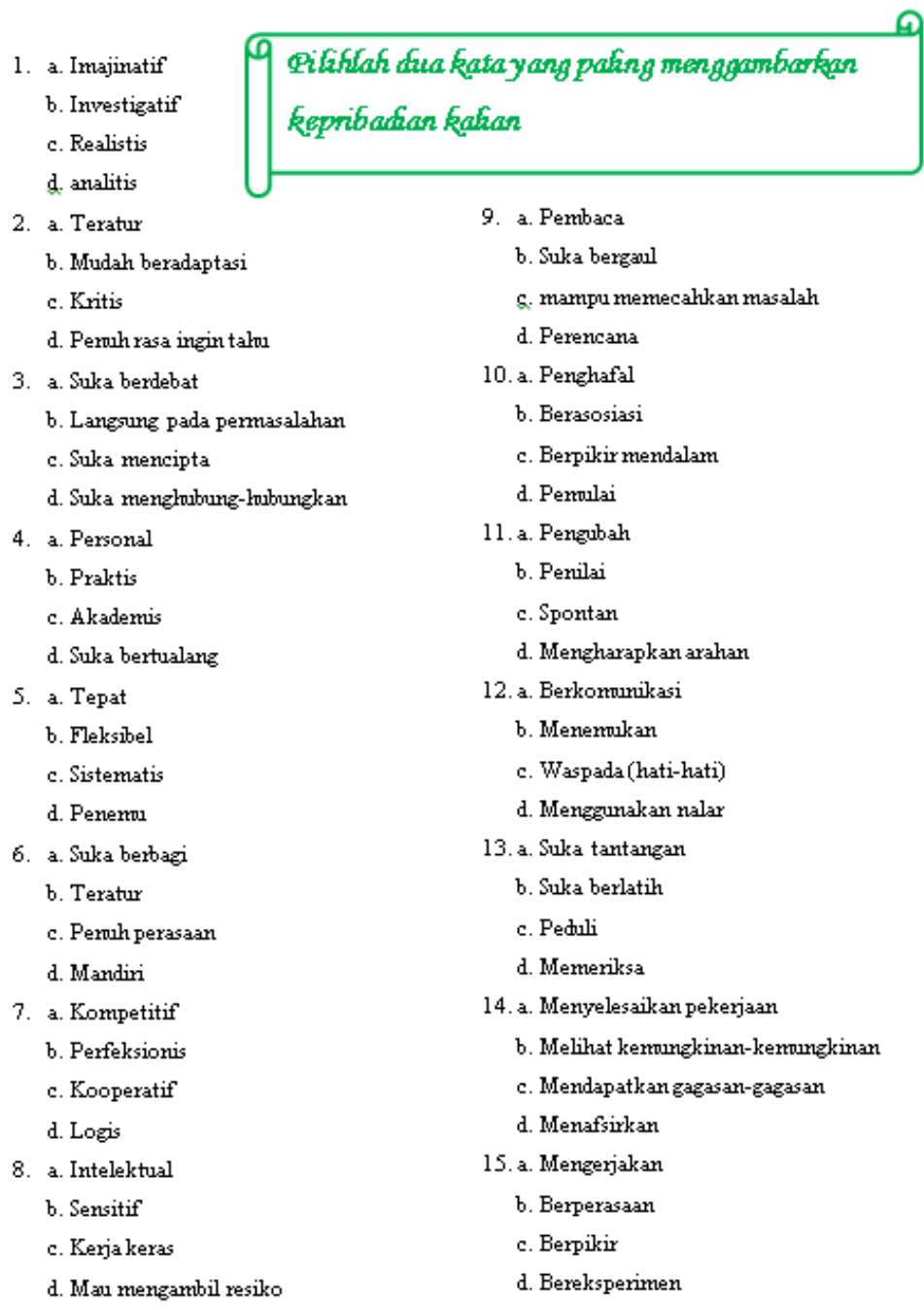

Gambar 1. Instrumen Tes Inventori Dominasi Otak

Peserta tes inventori ini diminta untuk memilih dua kata yang paling tepat menggambarkan dirinya dari empat kata yang disiapkan disetiap kelompok kata. Tidak ada jawaban yang dianggap benar atau salah dalam tes ini. Kejujuran dalam memilih kata yang paling tepat menggambarkan dirinya sangat penting dalam tes ini agar memperoleh hasil yang akurat. Hasil lembar jawaban siswa kemudian di analisis dan diperoleh siswa dengan dominasi otak kiri. Hasil tes inventori tersebut menunjukkan bahwa dari 32 orang siswa yang diujikan, delapan orang diantaranya merupakan siswa yang berdominasi otak kiri. Akan tetapi dalam penelitian ini peneliti hanya akan membahas dua orang siswa yang berdominasi otak kiri. Subjek ini dipilih karena berdasarkan analisis hasil tes inventori menunjukkan bahwa diantara delapan orang tersebut dua orang siswa ini yang benar-benar dominan dalam menggunakan otak kiri. 
Siswa berdominasi orat kiri ini dipilih karena menurut teori belahan otak, belahan otak kiri adalah bagian yang memproses data kuantitatif seperti matematika dan juga kemampuan berpikir rasional. Hal ini dapat dilihat pada tabel 1 di bawah ini.

Tabel 1. Fungsi Belahan Otak Kiri dan Belahan Otak Kanan (Ali \& Asrori, 2018; Danim, 2010)

\begin{tabular}{lllr}
\hline No. & Belahan Otak Kiri & Belahan Otak Kanan & \\
\hline 1. & Math, Hystory, Language & $\begin{array}{l}\text { Self, Elaborate and } \\
\text { Variable, Intentive }\end{array}$ & Increase \\
2. & Verbal, Limit sensory, input & $\begin{array}{l}\text { Nonverbal perception } \\
\text { expressiveness }\end{array}$ & and \\
& & Spatial & \\
3. & Sequential, measurable & Intuitive & \\
4. & Analytic & Holistic \\
5. & Comparative & Integrative \\
6. & Relational & Nonreferential & \\
7. & Referential & Gestalt \\
8. & Linier & Imagery \\
9. & Logical & Better at deepth perception, facial \\
10. & Digital & recognition \\
& & Mystical, humanistyc & \\
11. & Scientific, technological & Holistik \\
12. & Rasional & Subjektif \\
13. & Objektif & Melihat Keutuhan \\
14. & Melihat bagian & & \\
\hline
\end{tabular}

Teknik pengumpulan data yang digunakan dalam penelitian ini adalah menggunakan teknik Tes dan Wawancara. Teknik tes digunakan ketika siswa diminta menyelesaikan soal PISA. Salah satu Soal PISA yang digunakan dalam penelitian ini adalah soal PISA konteks “Dukungan untuk Presiden” seperti pada gambar 2 di bawah ini.

\section{DUKUNGAN UNTUK PRESIDEN}

\section{Pertanyaan 1: DUKUNGAN UNTUK PRESIDEN \\ M702001.0129 \\ Di negara Zedland, jajak pendapat dilaksanakan untuk mengetahui berapa besar dukungan untuk Presiden dalam pemilu mendatang. Empat surat kabar masing-masing melakukan survei jajak pendapat secara terpisah. Hasilnya adalah sebagai berikut: \\ Surat kabar 1: $36,5 \%$ (survei dilaksanakan pada 6 Januari, dengan 500 responden yang dipilih secara acak dari calon pemilih sah) \\ Surat kabar 2: 41,0\% (survei dilaksanakan pada 20 Januari, dengan 500 responden yang dipilih secara acak dari calon pemilih sah) \\ Surat kabar 3: $39 \%$ (survei dilaksanakan pada 20 Januari, dengan 1000 responden yang dipilih secara acak dari calon pemilih sah)}

Surat kabar 4: 44,5\% (survei dilaksanakan pada 20 Januari, dengan 1000 responden yang disurvei melalui telepon)

Surat kabar manakah yang mempunyai perkiraan terbaik untuk hasil pemilu sebenarnya yang akan dilaksanakan pada 25 Januari? Berikan dua alasannya:

Gambar 2. Soal PISA konteks Dukungan untuk Presiden 
Selanjutnya dalam pengumpulan data peneliti juga menggunakan teknik wawancara. Teknik wawancara digunakan untuk mendalami kemampuan berpikir rasional siswa, baik ketika siswa mengerjakan soal PISA maupun setelah siswa mengerjakan soal PISA yang diberikan. Metode wawancara yang digunakan dalam penelitian ini merupakan wawancara yang sifatnya tidak terstruktur, sangat tergantung pada respon siswa dan situasi yang terjadi di lapangan.

Teknik analisis data dalam penelitian ini menggunakan tahapan analisis data menurut Miles dan Huberman dengan tahapan: 1) Reduksi data; 2) Penyajian data; 3) Verifikasi atau penarikan kesimpulan (Sugiyono, 2012).

\section{HASIL DAN PEMBAHASAN}

Setelah memperoleh subjek penelitian yaitu siswa usia 15 tahun yang berdominasi otak kiri, tahap selanjutnya siswa tersebut diberikan soal PISA untuk melihat kemampuan berpikir rasionalnya. Kemampuan berpikir rasional siswa dilihat dari hasil lembar jawaban dan selanjutnya dilakukan wawancara untuk mendalami setiap indikator kemampuan berpikir rasional yang dilalui siswa ketika menyelesaikan soal PISA yang diberikan. Pada artikel ini akan diuraikan kemampuan dua orang siswa dengan dominasi otak kiri (OK). Dua subjek dengan dominasi otak kiri ini selanjutnya akan disebut dengan Siswa yang Berdominasi Otak Kiri Pertama (OK1) dan Siswa yang Berdominasi Otak Kiri Kedua (OK2). OK1 adalah siswa yang berdominasi otak kiri dengan kecenderungan pemikir Sekuensial Abstrak, sedangkan OK2 adalah siswa berdominasi otak kiri dengan kecenderungan pemikir Sekuensial Konkret. Adapun lembar jawaban dari dua orang siswa OK1 dan OK2 terhadap soal PISA konteks "Dukungan untuk Presiden" dapat dilihat pada gambar 3 dan 4 di bawah ini:

Surat kabar 3 , alasan:

1. karena responden telah mencapai 1000 orang yang melampaui dua surat kabar lainnta dan mentamai survei surat kabar ke 4.

2. karena surveinja direspon oleh pemilih sah.

Gambar 3. Jawaban OK1 terhadap Soal PISA konteks Dukungan untuk Presiden 


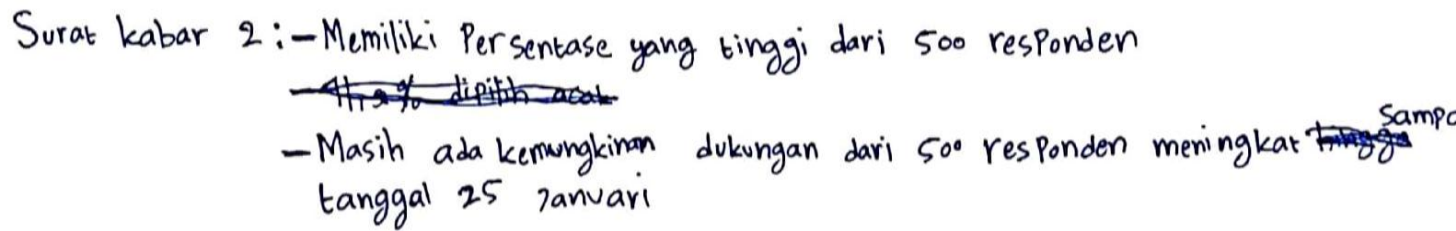

Gambar 4. Jawaban OK2 terhadap soal PISA konteks Dukungan untuk Presiden

Indikator kemampuan berpikir rasional dalam penelitian ini merujuk pada sepuluh indikator kemampuan berpikir rasional menurut Lawson (Lawson, 1980). Deskripsi tentang kemampuan berpikir rasional siswa OK1 dan OK2 akan dijelaskan disetiap indikatornya.

\section{Mengingat Kembali Informasi yang Diperoleh (Recalling)}

Kemampuan pada indikator pertama ini tidak dapat dilihat dari lembar jawaban yang diberikan oleh siswa, perlu dilakukan wawancara untuk memperoleh keterangan dari siswa OK1 dan OK2. Berdasarkan hasil wawancara yang dilakukan, peneliti menyimpulkan bahwa siswa OK1 dan OK2 mampu menjelaskan dengan baik semua informasi yang ada di dalam lembar soal PISA yang diberikan. Di bawah ini adalah penggalan transkrip wawancara antara peneliti (P) dan siswa OK1 dan siswa OK2.

Transkrip wawancara peneliti dan siswa OK1

P : "apa pertanyaannya?"

OK1 : "surat kabar manakah yang mempunyai perkiraan terbaik untuk hasil pemilu sebenarnya yang akan dilaksanakan pada 25 januari? Berikan dua alasan."

P : "yang dimaksud dengan responden ngerti? Apa itu responden?"

OK1 : "orang yang memberi respon"

$\mathbf{P} \quad$ : "kalau dipilih secara acak paham maksudnya?"

OK1 : "paham"

P : "kalo 39\% dari 1000 orang artinya berapa orang?"

OK1 : "390 orang."

P : "kalau $41 \%$ dari 500 orang artinya berapa orang?"

OK1 : "205 orang."

Transkrip wawancara peneliti dan siswa OK2

$\mathbf{P} \quad$ : "mengerti apa itu responden?"

OK2 : "mengerti."

$\mathbf{P} \quad$ : "kalau dipilih secara acak paham maksudnya?"

OK2 : "paham." 
Dari penggalan transkrip wawancara di atas dapat disimpulkan bahwa kedua subjek penleitian telah memenuhi indikator pertama kemampuan berpikir rasional yaitu mengingat kembali informasi yang diperoleh (Recalling).

Menurut Lawson (Lawson, 1980), kemampuan recalling akan bergantung pada kemampuan siswa dalam mengolah informasi yang telah diperoleh sebelumnya. Mengingat/menghafal informasi secara menyeluruh akan lebih baik daripada mengingat kata demi kata. Hal ini juga terbukti dalam penelitian ini dengan pemberian waktu yang cukup kepada siswa untuk membaca informasi secara menyeluruh, sehingga siswa mampu memahami dengan baik semua informasi yang diberikan di dalam soal yang diberikan.

\section{Membayangkan/Menggambarkan (Imagining)}

Kemampuan pada indikator kedua ini juga ditelusuri dengan melakukan wawancara kepada siswa OK1 dan OK2. Berdasarkan hasil wawancara maka dapat disimpulkan bahwa siswa OK1 dan OK2 dapat memenuhi indikator kedua dari kemampuan berpikir rasional. Mereka mampu membayangkan bahwa ada surat kabar yang mengambil jumlah populasi sebanyak 500 orang, ada yang melibatkan 1000 orang, akan tetapi mereka hanya melakukan survei kepada sebagiannya saja. Siswa OK1 dan OK2 juga mampu membayangkan bahwa survei yang dilakukan oleh surat kabar dilakukan secara acak, walaupun ada juga surat kabar yang melakukan melalui telepon. Responden yang disurvei oleh surat kabarpun beragam, ada surat kabar yang melibatkan responden yang berasal dari calon pemilih yang sah, ada juga surat kabar yang melakukan survei tanpa mempedulikan latar belakang respondennya.

Proses imagining ini juga penting diterapkan dalam praktek pembelajaran sebagai pendorong dan menjadikan proses pembelajaran menjadi bermakna (Lawson, 1980). Berdasarkan penjelasan dari Lawson tersebut, seorang guru matematika sebaiknya mengajak siswa dalam proses imagining (membayangkan) pada materi yang diajarkan agar pembelajaran yang dilakukan akan menjadi lebih bermakna.

\section{Mengelompokkan Informasi (Classifying)}

Indikator selanjutnya adalah mengelompokkan informasi. Dalam hal ini OK2 terlihat melakukan beberapa kesalahan. Beberapa kesalahan yang dilakukan oleh OK2 diantaranya: pertama, kurang cermat melihat persentase responden yang diambil dari populasi yang berbeda oleh masing-masing surat kabar. OK2 beranggapan bahwa surat kabar 2 memiliki responden yang lebih banyak daripada surat kabar 3 yang jika dilihat 
persentasenya memang surat kabar 2 lebih tinggi yaitu 41\%, sedangkan surat kabar 3 sebesar 39\%. Akan tetapi OK2 tidak memperhatikan bahwa surat kabar 2 dan 3 memiliki populasi yang berbeda. Surat kabar 2 memilih secara acak $41 \%$ dari 500 responden yang ada, sedangkan surat kabar 3 memilih secara acak 39\% dari 1000 orang responden. Jika dikalkulasikan maka surat kabar 2 hanya melakukan survei terhadap 205 orang responden, sedangkan surat kabar 3 melakukan survei terhadap 390 orang responden. Jika dilihat dengan lebih cermat maka walaupun secara persentase surat kabar 3 lebih sedikit, karena diambil dari populasi yang lebih banyak bahkan dua kali lipat dari populasi surat kabar 2 maka dapat disimpulkan bahwa jumlah responden yang disurvei oleh surat kabar 3 pasti akan lebih banyak dari surat kabar 2 .

Kesalahan kedua dari OK2 adalah kurangnya pemahaman tentang pentingnya memilih responden yang berasal dari calon pemilih yang sah. Siswa OK2 sempat berpikir untuk mengganti jawabanya dengan memilih surat kabar 4 sebagai surat kabar yang memiliki perkiraan terbaik untuk hasil pemilu sebenarnya. Hal ini didasarkan oleh pengetahuan barunya tentang persentase dan jumlah populasi berpengaruh terhadap menentukan jumlah responden yang disurvei. Jika dibandingkan dengan tiga surat kabar lainnya, maka secara jumlah memang surat kabar 4 yang memiliki jumlah responden yang disurvei paling banyak, yaitu 44,5\% dari 1000 orang atau sebanyak 445 orang. Akan tetapi siswa OK2 tidak menyadari bahwa teknik survei yang dilakukan oleh surat kabar 4 ini adalah melalui telepon dan tidak dijelaskan bahwa responden yang disurvei berasal dari calon pemilih yang sah. Hal ini tentu saja akan berpengaruh terhadap ketepatan hasil survei.

Dalam situasi yang diberikan pada soal PISA ini, survei yang baik adalah survei yang dilakukan terhadap calon pemilih tetap, dilakukan secara acak, semakin banyak responden yang disurvei maka data yang diperoleh akan menjadi lebih akurat, serta dilakukan menjelang detik-detik terakhir pemilihan berlangsung. Kesalahan OK2 dalam mengelompokkan informasi pada tahap ini tentunya akan mengarahkan ia kepada kesimpulan yang salah. Berikut adalah penggalan wawancara yang dilakukan dengan siswa OK2.

$$
\begin{array}{ll}
\mathbf{P} & : \text { :apa pilihannya tadi?" } \\
\text { OK2 : "surat kabar 2" } \\
\mathbf{P} & \text { : "kenapa?" } \\
\text { OK2 : "karena surat kabar } 2 \text { lebih tinggi dari surat kabar } 1 \text { yang sama-sama berjumlah 500" } \\
\mathbf{P} \quad \text { : "kalo surat kabar } 4 \text { ?" }
\end{array}
$$


OK2 : "o iya, harusnya surat kabar 4"

Siswa OK1 mampu mengelompokkan informasi dengan baik, hal ini terlihat jelas ketika peneliti melakukan wawancara untuk mendalami jawaban yang diberikan oleh OK1. Hasil wawancara menyimpulkan bahwa siswa OK1 mampu memahami dengan baik semua informasi yang diberikan pada soal PISA konteks "Dukungan untuk Presiden” ini. Hal ini memperkuat teori bahwa siswa pemikir Sekuensial Acak suka berpikir dalam konsep dan menganalisis suatu informasi dikarenakan proses berpikir mereka yang logis, rasional, dan intelektual (DePorter \& Hernacki, 2013). Di bawah ini merupakan transkrip wawancara yang dilakukan terhadap siswa OK1.

P : "apa pertanyaannya?"

OK1 : "surat kabar manakah yang mempunyai perkiraan terbaik untuk hasil pemilu sebenarnya yang akan dilaksanakan pada 25 januari? Berikan dua alasan.”

$\mathbf{P} \quad$ : "jadi yang mana?"

OK1 : "menurut saya yaitu surat kabar 3. Alasannya yang pertama karena respondennya telah mencapai 1000 orang, lebih banyak dibandingkan dua surat kabar lainnya dan sama dengan jumlah responden surat kabar 4. Alasan keduanya adalah karena direspon oleh calon pemilih yang sah, sedangkan surat kabar 4 tidak berasal dari calon pemilih yang sah dan dilakukan tidak secara acak, bahkan hanya melalui telepon."

Jenis informasi yang dapat di klasifikasikan adalah informasi yang mendefinisikan kriteria dalam objek yang diklasifikasikan (Lawson, 1980). Secara teori, soal yang diujikan telah memenuhi unsur tersebut. Soal yang diujikan telah memiliki kriteria yang harus dimiliki sebuah survei agar memperoleh hasil prediksi yang akurat dan tepercaya diantaranya responden yang dipilih berasal dari pemilih yang sah, jumlah populasi, jumlah responden yang dilibatkan, waktu pelaksanaan survei, dan teknik yang dilakukan untuk memperoleh data dari responden.

Lawson lebih lanjut menjelaskan bahwa kemampuan klasifikasi yang baik membutuhkan pemahaman konsep yang baik pula (Lawson, 1980). Berdasarkan penjelasan ini maka dapat dipahami alasan mengapa siswa OK2 melakukan kesalahan dalam mengklasifikasikan informasi yang diberikan. Hal ini dikarenakan pemahaman siswa yang masih kurang terhadap konsep syarat memperoleh hasil survei yang baik. Sehingga selanjutnya siswa hanya menebak-nebak saja sesuai pengetahuannya saja. Sebaliknya siswa OK1 dapat melakukan klasifikasi informasi dengan baik karena ia dapat memahami 
dengan baik apa saja syarat melakukan sebuah survei yang baik dan tepercaya, sehingga ia mampu mengklasifikasikan informasi yang diberikan dengan baik.

\section{Melakukan Generalisasi (Generalizing)}

Setelah mengelompokkan informasi yang diperoleh, siswa OK1 dan OK2 melakukan generalisasi. Informasi yang ada diolah sedemikan rupa sehingga mengarahkan mereka kepada beberapa hal yang perlu diperhatikan agar survei yang dilakukan oleh surat kabar tersebut memperoleh hasil yang akurat. Hasil wawancara menyimpulkan bahwa siswa OK1 dan OK2 memahami dengan baik bahwa beberapa hal yang mempengaruhi tingkat keakuratan hasil survei yang dilakukan surat kabar adalah jumlah populasi responden, jumlah responden yang dilibatkan, cara melakukan survei, dan waktu pelaksanaan survei.

Dalam melakukan proses generalisasi, siswa harus mampu menyadari bahwa proses generalisasi melibatkan pengakuan bahwa beberapa peristiwa adalah contoh atau bagian dari kejadian yang lebih besar (Lawson, 1980). Dalam konteks penelitian ini, kejadian yang dimaksud adalah kegiatan survei terhadap pemilihan presiden yang akan dilakukan. Survei merupakan kejadian kecil yang digunakan untuk memprediksi kejadian yang lebih besar yaitu hasil dari pemilihan presiden yang sebenarnya. Hasil penelitian menunjukkan bahwa siswa OK1 dan OK2 telah dapat melakukan generalisasi dengan baik terhadap situasi yang diberikan.

\section{Membandingkan (Comparing)}

Proses comparing (membandingkan) merupakan proses yang melibatkan pengakuan bahwa beberapa peristiwa memiliki perbedaan dari peristiwa lainnya (Lawson, 1980). Dalam konteks penelitian ini beberapa peristiwa yang dimaksud adalah pilihan jawaban merupakan bentuk peristiwa yang dilakukan oleh beberapa surat kabar sebagai lembaga survei. Setiap surat kabar melakukan survei dengan cara yang berbeda, melibatkan jumlah dan responden yang berbeda, dan waktu yang berbeda pula. Siswa harus mampu melihat dan memilih surat kabar mana yang memenuhi syarat terpenuhinya lembaga survei yang akurat dan tepercaya.

Siswa OK1 dapat membandingkan informasi yang ada di dalam soal PISA konteks "Dukungan untuk Presiden" dengan baik. Hal ini terlihat dari kemampuan siswa menjelaskan alasan yang dikemukakan dengan baik dan tepat pada lembar jawaban. Siswa OK1 mampu melihat bahwa jumlah populasi responden yang terbanyak berjumlah 1000 
orang. Selain itu, siswa OK1 juga memahami bahwa survei yang baik adalah survei yang melibatkan sampel yang banyak, hal ini dapat dilihat dari persentase responden yang dilibatkan dalam survei yang dilakukan oleh surat kabar. Selanjutnya siswa OK1 juga dapat memahami dengan baik bahwa hasil survei yang akurat adalah survei yang melibatkan responden yang berasal dari calon pemilih yang sah.

Pada indikator membandingkan ini, siswa OK2 juga memiliki kemampuan membandingkan yang cukup baik. Siswa OK2 memahami bahwa survei yang baik adalah survei yang melibatkan banyak orang. Hanya saja siswa OK2 melakukan kesalahan dalam penafsiran dari persentase yang diberikan oleh surat kabar. Siswa OK2 melihat bahwa surat kabar 2 memiliki persentase yang lebih tinggi dari surat kabar 1 yang sama-sama melibatkan 500 orang. Siswa OK2 juga tidak menyadari bahwa jumlah responden dari surat kabar 3 yang jumlahnya 39\% dari 1000 orang responden lebih banyak daripada surat kabar 2 yang berjumlah $41 \%$ dari 500 orang. Kesalahpahaman inilah yang menjadi penyebab utama siswa OK2 melakukan kesalahan dalam mengambil kesimpulan.

\section{Mengevaluasi (Evaluating)}

Kemampuan siswa dalam melakukan evaluasi (evaluating) berhubungan erat dengan kemampuan pada indikator kemampuan sebelumnya. Jika siswa telah melakukan kekeliruan pada tahapan sebelumnya, maka siswa tersebut akan menghasilkan evaluasi yang keliru pula. Lawson (Lawson, 1980) menjelaskan bahwa mengevaluasi melibatkan proses membuat keputusan yang biasanya membutuhkan proses generalisasi atau comparing (membandingkan).

Berdasarkan penjelasan Lawson di atas dapat disimpulkan bahwa proses mengevaluasi ini sangat erat kaitannya dengan proses generalisasi atau proses membandingkan. Sehingga jika terjadi kesalahan pada salah satu proses tersebut, maka akan dapat menyebabkan kesalahan pula dalam melakukan evaluasi. Dalam penelitian ini, siswa OK2 yang telah melakukan kekeliruan dalam memahami informasi yang diberikan pada proses sebelumnya mengakibatkan siswa OK2 melakukan kesalahan dalam proses membandingkan, sehingga siswa OK2 melakukan evaluasi yang tidak tepat. Sebaliknya, siswa OK1 telah memiliki kemampuan classifying dan comparing yang baik, sehingga hal ini membantu siswa OK1 dalam melakukan evaluasi dengan baik. 


\section{Menganalisa (Analyzing)}

Pada tahapan menganalisis ini subjek OK1 menghubungkan setiap informasi yang diperoleh. Siswa OK1 melakukan perhitungan terkait jumlah responde yang paling banyak dilibatkan oleh surat kabar hingga diperoleh surat kabar 3 yaitu 390 orang dan surat kabar 4445 orang. Akan tetapi siswa OK1 memahami bahwa survei yang akurat itu adalah survei yang dilakukan terhadap calon pemilih yang sah. Sehingga pilihan terbaik siswa OK1 tertuju kepada surat kabar 3.

Siswa OK1 yang telah melakukan kesalahpahaman di awal melakukan analisis sesuai dengan persepsinya saat itu, ia beranggapan bahwa untuk jumlah populasi 500 orang, surat kabar 2 melibatkan reponden yang lebih banyak dibandingkan surat kabar 1. Selain itu baik surat kabar 1 dan surat kabar 2 sama-sama memilih secara acak responden dari calon pemilih yang sah. Sehingga pilihan terbaik menurut analisa siswa OK2 tertuju kepada surat kabar 2.

Proses menganalisa ini erat kaitannya dengan proses mengklasifikasi, membandingkan dan mengevaluasi (Lawson, 1980). Untuk menganalisis informasi yang membantu siswa untuk dapat menuju kepada kesimpulan yang benar, siswa harus mampu melakukan proses membandingkan semua proses survei yang dilakukan oleh keempat surat kabar dengan baik. Artinya siswa harus mampu melakukan proses membandingkan dengan baik agar memperoleh hasil analisa yang baik. Seperti yang telah dijelaskan pada proses membandingkan sebelumnya, siswa OK1 dapat melakukannya dengan baik. Sedangkan siswa OK2 tidak dapat melakukan proses membandingkan dengan baik yang disebabkan oleh kurangnya pemahaman siswa tersebut terhadap konsep melakukan survei yang baik agar memperoleh hasil yang akurat dan tepercaya.

\section{Melakukan Sintesis (Synthesizing)}

Pada tahapan melakukan sintesis ini, siswa OK1 mencoba membandingkan dan mengevaluasi kembali pilihan yang telah ditetapkan. Siswa OK1 mencoba mengevaluasi pilihan lain yaitu surat kabar 1, 2 dan 4. Surat kabar 1 dan 2 sama-sama memilih secara acak respondennya dari populasi sebanyak 500 orang. Perbedaan kedua surat kabar ini terletak pada jumlah responden yang disurvei, surat kabar 1 melakukan survei terhadap 183 orang sedangkan surat kabar 2 melakukan survei terhadap 205 orang. Berdasarkan perbandingan tersebut, maka hasil survei surat kabar 2 dipercaya lebih baik daripada surat kabar 1. Selanjutnya surat kabar 4, jumlah responden yang disurvei berjumlah 445 orang. Akan tetapi responden ini bukanlah berasalah dari calon pemilih yang sah, sehingga hasil 
survei yang dilakukan diragukan ketepatannya apalagi survei dilakukan hanya melalui telepon.

Proses Sintesis erat kaitannya dengan mengelompokkan informasi (Classifying), melakukan generalisasi (Generalizing), membandingkan (Comparing) dan evaluasi (Evaluation) (Lawson, 1980). Setelah malalui tahapan mengelompokkan informasi, melakukan generalisasi, membandingkan dan evaluasi dengan benar, maka pada tahapan melakukan sintesis ini siswa OK1 dapat melakukan dengan benar dengan melibatkan semua informasi yang telah di analisis pada tahapan sebelumnya. Sehingga diperoleh kebenaran informasi secara berkesinambungan.

\section{Melakukan Deduksi (Deducing)}

Dari proses yang telah dilakukan sebelumnya, pada tahapan melakukan deduksi ini siswa telah memantapkan diri terhadap pilihan yang diambil melalui serangkaian tahapantahapan berpikir pada tahap sebelumnya. Berdasarkan semua informasi yang diperoleh, kemudian di klasifikasikan, selanjutnya informasi tersebut digeneralisasikan sehingga mengerucut pada suatu pilihan. Ketepatan dalam memilih pada tahapan ini tentunya sangat diperngaruhi pada ketepatan dalam melalui tahapan-tahapan berpikir rasional sebelumnya. Siswa OK1 yang mampu melalui semua tahapan dengan baik dan benar maka memperoleh pilihan yang tepat pula. Sedangkan siswa OK2 yang melakukan kesalahan didalam memahami informasi yang ada berakibat pada kesalahan-kesalahan pada tahapan berpikir rasional ditahap selanjutnya.

Proses deduksi ini erat kaitannya dengan proses klasifikasi atau generalisasi, tetapi beberapa deduksi juga erat kaitannya dengan proses sintesis (Lawson, 1980). Sejalan dengan hal tersebut, jelas mudah bagi siswa OK1 dalam melakukan deduksi dengan baik dan benar terhadap informasi yang diberikan. Siswa OK1 berhasil membuat deduksi dengan baik berdasarkan tahapan berpikir rasional sebelumnya.

\section{Kesimpulan (Infering)}

Tahap ini adalah muara dari semua tahapan berpikir rasional, yaitu menarik kesimpulan. Proses menarik kesimpulan ini mungkin akan melibatkan seluruh tahapan berpikir rasional yang telah dilakukan sebelumnya (Lawson, 1980). Siswa OK1 meyakini bahwa dari informasi yang ada, surat kabar yang mempunyai perkiraan terbaik untuk hasil pemilu sebenarnya adalah surat kabar 3. Hal ini dikarenakan surat kabar 3 melibatkan 390 orang responden yang dipilih secara acak dan berasal dari calon pemilih yang sah. 
Sedangkan OK2 mengambil kesimpulan yang keliru, bahwa surat kabar 2 merupakan surat kabar yang mempunyai perkiraan terbaik.

\section{KESIMPULAN}

Berdasarkan hasil analisis yang peneliti lakukan, maka ada beberapa indikator kemampuan berpikir rasional yang tidak dapat dipenuhi oleh siswa yang berdominasi otak kiri dalam menyelesaikan soal PISA. Adapun beberapa indikator kemampuan berpikir rasional yang menjadi kesulitan bagi siswa adalah kemampuan mengelompokkan informasi (classifying), mengevaluasi, dan menganalisa. Kesalahan ini terjadi karena siswa kurang cermat dalam memahami informasi yang diberikan. Siswa kurang memahami bahwa hasil survei yang baik diperoleh dari survei yang melibatkan calon pemilih tetap, dilakukan secara acak, semakin banyak responden yang dilibatkan maka semakin akurat pula prediksi hasil survei yang dihasilkan, serta survei yang baik adalah survei yang dilakukan pada beberapa hari menjelang pemilihan presiden dilakukan.

\section{UCAPAN TERIMAKASIH}

Penelitian ini merupakan Penelitian Dosen Pemula yang didanai oleh Direktorat Riset dan Pengabdian kepada Masyarakat (DRPM).

\section{DAFTAR PUSTAKA}

Ali, M., \& Asrori, M. (2018). Psikologi Remaja Perkembangan Peserta Didik (Tiga Belas). Jakarta: PT. Bumi Aksara.

Artika, T., \& Karso, K. (2019). Meningkatkan Kemampuan Pemecahan Masalah Matematis Siswa Dengan Menggunakan Metode Pembelajaran Thinking Aloud Pair Problem Solving (Tapps). Prisma, 8(2), 191-200. https://doi.org/10.35194/jp.v8i2.791

Baron, J. (2008). Thinking and Deciding. Fourth Edition. (Fourth). New York: Cambridge University Press.

Danim, S. (2010). Perkembangan Peserta Didik (Kesatu). Bandung: CV. ALFABETA.

DePorter, B., \& Hernacki, M. (2013). Quantum Learning Membiasakan Belajar Nyaman dan Menyenangkan. Bandung: Kaifa.

Fitra, D., Putri, R. I. I., \& Susanti, E. (2018a). Pisa-Like Mathematics Task Using WeightLifting Context. 5th International Conference on Research, Implementation and Education of Mathematics and Sciences, 387-392. Yogyakarta: Faculty Of Mathematics And Natural Sciences Yogyakarta State University.

Fitra, D., Putri, R. I. I., \& Susanti, E. (2018b). Soal serupa pisa menggunakan konteks cabang olahraga lari. Jurnal Inovasi Edukasi, 1(1).

Gunawan, I. (2013). Metode Penelitian Kualitatif Teori \& Praktik. Jakarta: Bumi Aksara. Jupri, A., \& Drijvers, P. (2016). Student Difficulties in Mathematizing Word Problems in Algebra. Eurasi Journal of Mathematics, Science \& Technology Education, 12(9), 
2481-2502. https://doi.org/10.12973/eurasia.2016.1299a

Jusniani, N. (2018). Analisis Kesalahan Jawaban Siswa pada Kemampuan Pemahaman Matematis melalui Pembelajaran KontekstuaL. PRISMA, $7(1), \quad 82$. https://doi.org/10.35194/jp.v7i1.361

Kemendikbud. (2014). Permen 58 tahun 2014 lampiran PMP MTK SMP. Indonesia.

Kemendikbud. (2016). Peraturan Menteri Pendidikan dan Kebudayaan Nomor 20 tentang Standar Kompetensi Lulusan Pendidikan Dasar dan Menengah. Jakarta: Kemendikbud RI.

Lawson, A. E. (1980). Science Education Information Report. Arizona: Arizona State University.

Lutfianto, M., Zulkardi, \& Hartono, Y. (2013). Unfinished Student Answer In PISA Mathematics Contextual Problem. Journal On Mathematics Education (IndoMS$J M E), 4(2), 201-208$.

Maulani, R. L., Ruseffendi, H. E. ., \& Kustiana. (2019). Improving Students' Critical Thinking Ability and Resiliency Using Problem-Solving Approach. PRISMA, 8(1), 26-36.

OECD. (2019). PISA 2018 Results (Volume I): What Students Know and Can Do. Paris: OECD Publishing.

Putri, R. I. I., Gunawan, M. S., \& Zulkardi. (2017). Learning Fraction through Swimming Context for Elementary School Student. 5th SEA-DR (South East Asia DEvelopment Research) International Conference 2017 (SEADRIC 2017). Makasar: Atlantis Press.

Septian, A., Darhim, \& Prabawanto, S. (2020). Mathematical Representation Ability Through Geogebra-Assisted Project-Based Learning Models. Journal of Physics: Conference Series, 1657(1), 012019. https://doi.org/10.1088/17426596/1657/1/012019

Septian, A., \& Komala, E. (2019). Kemampuan Koneksi Matematik dan Motivasi Belajar Siswa dengan Menggunakan Model Problem-Based Learning (PBL) Berbantuan Geogebra di SMP. PRISMA, 8(1), 1-13. https://doi.org/10.35194/jp.v8i1.438

Soleh, E. R. A., Setiawan, W., \& Haqi, R. (2020). Upaya Meningkatkan Kemampuan Komunikasi Matematis dan Aktivitas Belajar Siswa Menggunakan Model Problem Based Learning. Prisma, 9(1), 1. https://doi.org/10.35194/jp.v9i1.798

Sugiyono. (2012). Metode Penelitian Kuantitatif Kualitatif dan R\&D. Bandung: Alfabeta.

Wulandari, N. Y. (2019). Meningkatkan Kemampuan Koneksi Matematik Siswa SMP dengan Menggunakan Pendekatan Realistic Mathematic Education. PRISMA, 8(1), $14-24$. 